\title{
A MENNYISÉGI KEDVEZMÉNY ÉS A VISSZAVÁSÁRLÁSI SZERZŐDÉS ELLÁTÁSI LÁNCON BELÜL TÖRTÉNŐ ALKALMAZÁSI LEHETŐSÉGEINEK VIZSGÁLATA
}

\section{EXAMINATION OF THE APPLICATION POSSIBILITIES OF QUANTITY DISCOUNT AND BUY-BACK CONTRACT WITHIN THE SUPPLY CHAIN}

\author{
Faludi Tamás ${ }^{1}$ \\ 1 Vezetéstudományi Intézet, Gazdaságtudományi Kar, Miskolci Egyetem, Magyarország \\ https://doi.org/10.47833/2021.1.ECO.002
}

\section{Kulcsszavak:}

ellátásilánc-menedzsment ellátásilánc-koordináció szerződéstípusok visszavásárlási szerződés mennyiségi kedvezmény

\section{Keywords:}

supply chain management supply chain coordination contract types buy-back contract quantity discount

\section{Cikktörténet:}

Beérkezett 2021. március 8. Átdolgozva 2021. március 20. Elfogadva 2021. április 3.

\begin{abstract}
Összefoglalás
Jelen tanulmány célja megvizsgálni egy olyan partnerkapcsolatot az ellátási láncon belül, ahol a készletek minimális szinten történő tartása a cél. Ennek érdekében az ellátásilánc-koordináció által javasolt szerződéstípusok közül az ehhez a helyzethez legjobban alkalmazkodó mennyiségi kedvezmény és visszavásárlási szerződés alkalmazása javasolt. A tanulmány ezen szerződések vizsgálatát tartalmazza egy számszerü példával kiegészítve.
\end{abstract}

\begin{abstract}
The aim of the paper is to analyse the relationship within the two-stage supply chain, which prioritises the low level of stocks. To reach this goal the supply chain coordination recommends to use the quantity discount and the buy-back contract. The paper analyses the advantages and disadvantages of the using of these contracts. A numerical example is also included.
\end{abstract}

\section{Bevezetés - az ellátásilánc-koordináció fontossága}

Az ellátásilánc-menedzsment XXI. századi nagy kihívása a tagok folyamatainak összehangolása, melyek föként a végső felhasználó számára értéket teremtő termékekre és szolgáltatásokra összpontosulnak, hiszen ez lesz a feltétele annak, hogy a fogyasztói igények maradéktalanul ki legyenek elégítve [13]. Az ellátási láncok célja, hogy a kapcsolatban álló szervezetek értékteremtő folyamatait összehangolják, összekapcsolják, integrálják [1]. Ezek azok a folyamatok, melyek a lánc végén a fogyasztó részére értéket teremtenek. Magyarországon 2010-től egyre nagyobb ütemben fejlődő rövid ellátási láncok esetében, melyek többnyire élelmiszerláncok, ez a koordinációval kapcsolatos problémák nem befolyásolják nagymértékben a láncok

\footnotetext{
1 Kapcsolattartó szerző.

Email cím: szvft@uni-miskolc.hu
} 
teljesítményét, illetve hatékony müködését, hiszen ezen láncok nem annyira kiterjedtek és bonyolultak, mint a többi, globális szinten müködő láncok [5]. Utóbbi helyzetben ugyanis a vállalatok ellátásilánc-menedzsmentjének, illetve kapcsolatmenedzsmentjének legföbb problémáját a megnövekedett számú partnerek okozzák.

A fogyasztói társadalom által megnövekedett és széles spektrumban változó igények, valamint a vállalatok multinacionálissá válása lehetővé tette az ellátási láncok komplexebbé válását, vagyis azt, hogy minél több lánctag csoportosuljon egy láncon belülre. Ezért manapság már nagyon nagy tagszámmal rendelkező hálózatok jöttek létre, ahol az információáramlás, a modern IT támogatás, az információ-megosztási hajlandóság, a bizalom, és magának a láncnak a kontrolling rendszere nagy kihívást jelent mind a lánctagok, mint pedig a központi vállalat menedzsmentje számára. Ezért került előtérbe az ellátásilánc-menedzsment, mely egyfajta vállalatirányítási filozófiaként jelenik meg a vállalaton belül, és arra ösztönözi a lánc tagjait, hogy elsajátítsák az ellátási lánc koncepcióját. Az ellátási lánc koncepció lehetővé teszi a tagok számára a rendszer- és folyamatszemléletű hozzáállás kialakítását. Ennek segítségével a vállalatok képesek az ellátási láncot rendszerként kezelni, gyorsabb és hatékonyabb információ- és anyagáramlást tesz lehetővé, mely a dinamikusan változó piaci igényekhez és keresleti ingadozásokhoz történő alkalmazkodást segíti elő. Ezzel pedig költségeket lehet csökkenteni, mely a lánctagok és így az egész lánc müködésének hatékonyságát képes fokozni [6]. Az ellátásilánc-menedzsment ezzel foglalkozó ágazata az ellátásilánckoordináció, mely segít összehangolni a vállalat értékteremtő folyamatait, valamint menedzseli a partnerek kapcsolatait. A megnövekedett lánctagszám miatt felértékelődött az ellátásilánckoordináció fontossága.

A koordinációs tényezőket az ellátási láncok tekintetében két nagy csoportja sorolhatjuk. A puha tényezők a viselkedéstudomány irányából közelítik meg az ellátási láncok koordinációs kérdését és olyan tényezők tartoznak ide, mint a dominancia kérdése, a bizalom, a kommunikáció, és az információ-megosztási mechanizmusok [10]. A kemény tényezők csoportja a vállalatok együttműködésének finanszírozási oldala felöl vizsgálja a témát. Projektek, illetve a hozzá tartozó IT háttér és infrastruktúra által nyújtott támogatás, és a különböző szerzödéstípusok alkalmazásával történő koordináció a kemény tényezők fókuszterülete [12]. A szerződéstípusok alkalmazási lehetőségei és feltételei, valamint az alkalmazás sikerességének vizsgálatára összpontosítanak jelenleg a kutatások $[4,7,11]$.

A szerződések jelen esetben nem jogi aspektusból vizsgálandók. A külföldi szakirodalom tartalmuk alapján tipizálta ezeket a szerződéseket, és ezek alapján vizsgálja a koordinációs erejüket. Több definíció is létezik az ellátási láncon belül alkalmazott szerződésekre. Többnyire a tagok közötti egyenlötlenségek - melyek föként a kockázatok, költségek, előnyök és profitok egyenlőtlen megosztásából erednek - kezelésére alkalmazott koordinációs eszközként tekint rá a szakirodalom [2, 3, 15]. Sokféle szerződést különböztetnek meg a kutatók. Tradicionális szerződések [9, 15], szélsőséges típusok, melyek csak bizonyos piaci feltételek mellett alkalmazhatók [8], és viszonylag új megközelítések, vagy a hagyományos típusok egyes paramétereinek megváltoztatásával létrejött különleges típusok [14, 17] találhatók a szakirodalomban. Pontosan a sokszínüségük miatt jelenthetnek potenciálisan jó megoldást egy-egy koordinációs probléma esetén.

Jelen tanulmány célja bemutatni egyes szerződéstípusok koordinációra gyakorolt hatását. Célom két olyan típus vizsgálata, melyek koordinációs erejét legerőteljesebben a készletek mennyiségének változása befolyásolja. Szakirodalmi adatok alapján egy viszonylag gyakran alkalmazott és egy kevésbé ismert és használt szerződésre esett a választás [11].

A továbbiakban egy számszerü példával szeretném bemutatni a választott szerződések koordinációs erejét. A példa egy fiktív lánc adott szakaszát vizsgálja. A következő fejezet a számszerű példában szereplő ellátási lánc szakaszát mutatja be, majd a tagok attitűdjeihez, illetve magához a vázolt helyzethez legjobban illeszkedő szerződéstípusok bemutatása következik. Az eredmények kiértékelése és következtetések levonása után egy, a tanulmányt átfogó összegzés zárja a cikket.

\section{Számszerű példa}

A tanulmány két hasonló szerződés bemutatását tartalmazza. Feltételezek egy olyan ellátási lánc szakaszt, ahol a két partner együttmüködését legjobban befolyásoló tényező a mennyiség lesz 
- vagyis az értékesíthető mennyiség növelése és a készletek alacsonyan tartása a releváns és nagy befolyásoló erővel rendelkezik az együttmüködési megállapodás kialakításakor. A két partner a végső fogyasztóhoz legközelebb álló kiskereskedő (jelölése $K K$ ) és nagykereskedő (jelölése $N K$ ) lesz. A két tag önköltsége adott, melyet a példa ÖK-val fog jelölni. A láncon belül értékesíthető mennyiségért (jelölése ÉM) cserébe a kiskereskedő a nagykereskedőnek Á $N K$ jelölésű egységárat fizet, a kiskereskedő pedig az általa megállapított áron - mely tulajdonképpen a piaci ár - fogja a végső fogyasztó részére értékesíteni az árut, melynek jelölése $A_{K K}$. A teljes profiton (a profitértékeket a példában $\pi$ jelöli) a tagok egy elöre meghatározott arányban osztozkodnak, melyet az $\alpha$ szimbolizál. A piaci ár kiszámításához az inverz keresleti függvény lett alapul véve, melyben a piacot jellemző állandókat az $A$ és $B$ konstansok képviselnek. A példához tartozó információkat jelölésekkel együtt az 1. ábra foglalja össze.

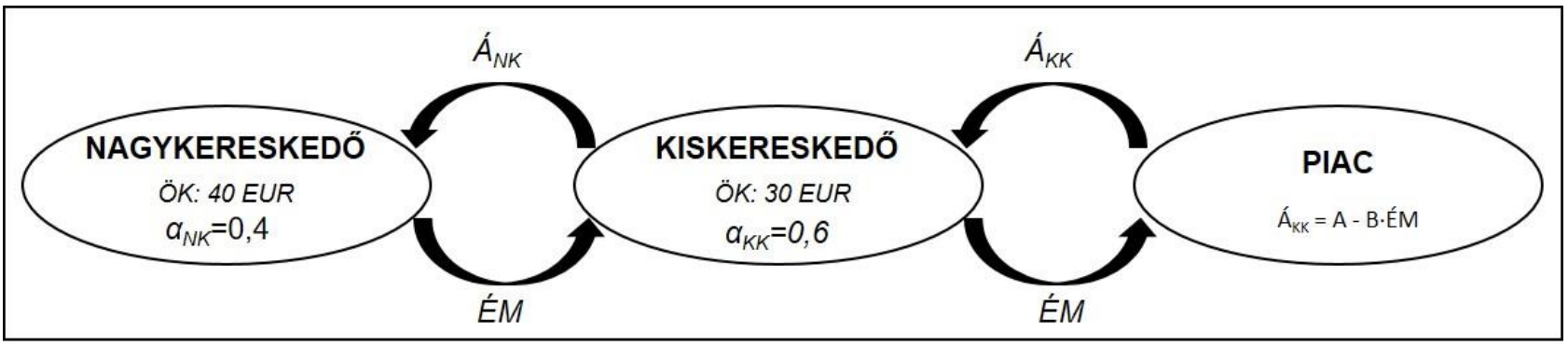

1. ábra: A példában alkalmazott ellátási lánc modell

Egy ilyen kapcsolathoz a szakirodalomban fellelhető típusok közül a legjobban illeszkedő a mennyiségi kedvezmény és a visszavásárlási szerződés lesz.

A szerződések koordinációs erejét a szerződés segítségével elérhető individuális és összprofit, valamint a piaci és egységárak nagysága alapján elemzem. Magas összprofit esetén az a következtetés vonható le, hogy a lánc vizsgált szakasza hatékonyan müködik. Ha ez az összprofit viszonylag arányosan oszlik meg a tagok között, akkor az azt feltételezi, hogy a tagok kooperációja is kielégítő, mert képesek olyan feltételekben megállapodni - vagyis olyan szerződést alkalmazni , melyek mindkét fél számára előnyösek; így alakíthatják ki - a szerepköröknek megfelelően arányos profitmegosztást. Tehát, ha egy szerződés képes olyan feltételeket kínálni a partnereknek, melyek segítségével a tagok által elfogadható relatíve alacsony egység- és piaciárakból a nagy értékesítési volumennek köszönhetően magas profitra tehetnek szert, akkor az a szerződés koordináció szempontjából pozitív elbírálást nyer, vagyis magas koordinációs erővel bír.

\subsection{A vizsgált szerződések bemutatása}

A mennyiségi kedvezmény lényege, hogy minél nagyobb volumenü rendelést ad le a kiskereskedő, annál nagyobb mértékű kedvezményt kap az egységárra. Így ez a szerződéstípus a kiskereskedőt a minél nagyobb rendelési tételnagyság megállapítására ösztönözi. Ezzel egyidejűleg az nagykereskedőnél fennáll az a veszély, hogy nem lesz elegendő készlete, így nem fogja tudni kielégíteni a kiskereskedő igényeit például egy hirtelen jött keresletnövekedés esetén. A ksikereskedő részéröl pedig kockázatot jelent a nagy rendelési tételnagyság, ugyanis ebben az esetben, ha csökken a piaci kereslet, akkor nagyobb mennyiségü készletet fog felhalmozni, ami jelentős többletköltséget jelent [9]. A mennyiségi kedvezmény értékesíthető mennyiségét az önköltségek és az inverz keresleti függvény segítségével fejezhető ki ((1) egyenlet). A nagykereskedő által meghatározott egységár a lánctag bevételének és költségeinek a különbségéből meghatározható profitértékből számolható ki ((3)-(4) egyenlet). Ezek segítségével a kiskereskedő profitegyenlete is meghatározható ((5) egyenlet).

$$
\begin{gathered}
\text { ÉM }=\frac{A-\left(O \mathrm{OK}_{\mathrm{NK}}+\ddot{O}_{\mathrm{KK}}\right)}{2 \cdot \mathrm{B}} \\
\hat{A}_{\mathrm{KK}}=\mathrm{A}-\mathrm{B} \cdot \mathrm{E} \mathrm{M}
\end{gathered}
$$




$$
\begin{aligned}
& \hat{A}_{\mathrm{NK}}=\alpha_{\mathrm{NK}} \cdot \frac{\left(\hat{A}_{\mathrm{KK}} \cdot \mathrm{E} M\right)}{\mathrm{É}^{\mathrm{M}}}-\ddot{O}_{\mathrm{KK}}+\alpha_{\mathrm{KK}} \cdot\left(\mathrm{ÖK}_{\mathrm{KK}}+\mathrm{O}_{\mathrm{NK}}\right) \\
& \pi_{\mathrm{NK}}=\left(\hat{A}_{\mathrm{NK}}-\mathrm{ÖK}_{\mathrm{NK}}\right) \cdot \mathrm{E} \mathrm{M} \\
& \pi_{\mathrm{KK}}=\left(\hat{A}_{\mathrm{KK}}-\hat{A}_{\mathrm{NK}}-\ddot{O}_{\mathrm{KK}}\right) \cdot \text { ÉM }
\end{aligned}
$$

A visszavásárlási szerződés egy empirikus kutatás szerint a vállalatok által preferált típus [11]. Ennek a szerződésnek az esetében is a szük keresztmetszetet a rendelési és értékesíthető mennyiség fogja adni. E típus lehetővé teszi, hogy a lánc adott szakaszán vevői szerepben tevékenykedő lánctag - a kiskereskedő - további értékesítésre szánt, de el nem adott termékeit a nagykereskedő egy meghatározott áron visszavásárolja. Így csökkenthetővé válik a kiskereskedő azon kockázata, mely a készletek felhalmozódására vonatkozik [16]. A visszavásárlási ár megállapítása nagyban befolyásolja a profit értékét, hiszen ez az egyik oldalon költséget fog okozni, míg a másikon tulajdonképpen egyfajta bevételt.. A visszavásárlási szerződés esetén az értékesíthető mennyiség, illetve a kiskereskedő által meghatározott ár kiszámítási módja megegyezik az (1) és (2) egyenlettel. Ez a szerződéstípus egy új ár-típust tartalmaz, melynek kiszámításához a (6) egyenlet alkalmazandó - ez lesz a visszavásárlási ár, melyet a nagykereskedő bevételi aránya és a kiskereskedő által meghatározott ár befolyásolja, hiszen ebben az esetben a nagykereskedő kötelezettséget vállal arra, hogy a kiskereskedő nem értékesített termékeit visszavásárolja. Ez a visszavásárlási ár befolyásolni fogja a nagykereskedői árat is ((7) egyenlet), illetve az egyes tagok profitegyenletét is ((8)-(9) egyenlet).

$$
\begin{gathered}
\hat{A}_{\mathrm{VV}}=\hat{A}_{\mathrm{KK}} \cdot\left(1-\alpha_{\mathrm{NK}}\right)=\alpha_{\mathrm{KK}} \cdot \hat{A}_{\mathrm{KK}} \\
\hat{A}_{\mathrm{NK}}=\frac{\mathrm{A}-\ddot{O}_{\mathrm{KK}}+\mathrm{ÖK}_{\mathrm{NK}}}{2} \\
\pi_{\mathrm{NK}}=\left(\hat{A}_{\mathrm{NK}} \cdot \mathrm{E} \mathrm{M}\right) \cdot\left(1-\frac{\hat{A}_{\mathrm{VV}}}{\hat{\mathrm{A}}_{\mathrm{NK}}}\right)-\left(\mathrm{ÖK}_{\mathrm{NK}}-\hat{A}_{\mathrm{VV}}\right) \cdot \mathrm{E} \mathrm{M} \\
\pi_{\mathrm{KK}}=\left(\hat{A}_{\mathrm{KK}} \cdot \mathrm{E} \mathrm{M}\right) \cdot\left(1-\frac{\hat{A}_{\mathrm{VV}}}{\hat{A}_{\mathrm{KK}}}\right)-\left(\hat{A}_{\mathrm{NK}}-\ddot{O}_{\mathrm{KK}}-\hat{A}_{\mathrm{VV}}\right) \cdot \mathrm{E} \mathrm{M}
\end{gathered}
$$

A továbbiakban e két szerződést fogom elemezni a következő tényezők alapján. A profit értéke minden vállalat életében kritikus pont, tulajdonképpen minél nagyobb a profit, annál sikeresebb a vállalat, vagyis minél nagyobb profittal rendelkezik egy vállalat, annál eredményesebbnek tekinthető a müködése. Ezért tartom fontosnak a profit szempontjából történő elemzést. Emellett, mivel a feltételezett partnerkapcsolatban fontos, hogy adott időszakon belül alacsonyan tudják tartani a tagok a készletszintet, fontosan tartom az adott láncban elérhető legmagasabb értékesíthető mennyiség szerinti vizsgálatot is. Fontos megjegyezni, hogy nem teljesmértékben összehasonlításról szól a következő alfejezet, hanem a szerződések alkalmazásának stratégiai jellegű fontosságát igyekszik hangsúlyozni egy számszerü példa segítségével. Ez azt jelenti, hogy az említett vizsgálati faktorok segítségével egy olyan képet kaphatunk a két szerződésről, mely segíthet egy szigorú készletpolitikát preferáló ellátási láncnak - ahol maximális prioritást élvez a készletszintek minimálisan történő tartása - eldönteni, hogy milyen jellegü szerződést érdemes választania a két tag közötti koordináció erősítése céljából. A számszerű példa eredményei alapján megismerhetővé válnak a két szerződés előnyei és hátrányai, illetve alkalmazásuk feltételei.

\subsection{Eredmények bemutatása és értelmezése}

Az előző fejezetben megismert egyenletek, adatok és információk alapján a vizsgált tényezők eredményei a következőképpen alakulnak (1. táblázat). 
A mennyiségi kedvezmény és a visszavásárlási szerződés ellátási láncon belül történő alkalmazási lehetőségeinek vizsgálata

1. Táblázat: A számszerü példa eredményei

\begin{tabular}{|lr|c|c|}
\hline & & Mennyiségi kedvezmény & Visszavásárlási szerzödés \\
\hline ÉM & {$[100 \mathrm{db}]$} & 30 & 30 \\
\hline$\dot{A}_{\mathrm{NK}}$ & {$[\mathrm{EUR}]$} & 85 & 85 \\
\hline$\dot{A}_{K K}$ & {$[\mathrm{EUR}]$} & 46 & 55 \\
\hline$\pi_{N K}$ & {$[100 \mathrm{EUR}]$} & 180 & 450 \\
\hline$\Pi_{K K}$ & {$[100 \mathrm{EUR}]$} & 270 & 965 \\
\hline$\Pi_{\text {total }}$ & {$[100 \mathrm{EUR}]$} & 450 & 1415 \\
\hline
\end{tabular}

A számpélda eredményeit tartalmazó 1. táblázat által bemutatott értékek alapján feltételezhető, hogy a visszavásárlási szerződés alkalmazása jelentheti az optimális megoldást a koordináció erősítése szempontjából. Ennél a típusnál a kiskereskedő által meghatározott ár, vagyis a piaci áron kívül minden egyéb tényező vagy ugyanolyan jó, vagy pedig kimagaslóan jobb, mint a mennyiségi kedvezmény esetében. Milyen előnyökkel és milyen hátrányokkal járhat azonban ez a választás?

Elsősorban a visszavásárlási szerződésben található visszavásárlási árat kell szemügyre venni. Ez egy költségnövelő tényező, melyet nem feltétlenül vállalnak be az ellátási láncon belül tevékenykedő vállalatok. Vannak úgynevezett árérzékeny vállalatok, melyek a legkisebb áremelkedésre vagy árváltozásra is fokozottan negatívan reagálnak. Ebben az esetben a vállalat akár azonnal partnert válthat, szerződést bonthat, tulajdonképpen elmenekül a magasabb árak elöl. Ezért egy ilyen attitűddel rendelkező vállalat nem feltétlenül biztos, hogy megköt egy visszavásárlási szerződést a partnerével. Pedig láthatóan magas profitértékeket produkál, ami minden vállalat számára vonzó. Ennek az oka az, hogy már a nagykereskedő által definiált árat is befolyásolja a visszavásárlási ár, és mivel a visszavásárlási ár függ a kiskereskedői egységártól, így hatást gyakorol voltaképpen már a kiskereskedői ár is a nagykereskedői ár megállapítására. Ezek a tényezők pedig az individuális profitegyenletek részei, ezért észlelhetők a megnövekedett profitértékek mindkét tagnál.

A mennyiségi kedvezmény tradicionális jellegü típusnak tekinthető, amelynek célja az értékesítés intenzitásának növelése. Hagyományos jellege abból ered, hogy semmilyen extra tényező nem befolyásolja az értékek kiszámítását. Mivel itt egy ár-tényezővel kevesebb jelenik meg - hiszen itt nincs visszavásárlási ár -, kisebbek lesznek az ár és profit értékei is. Nincs kizárva az, hogy mindkét tag egyidejüleg alkalmazza a saját vevőjével szemben a bemutatott szerződéseket, vagyis így a kiskereskedő is serkentheti eladási rátáját a piacon, amennyiben mennyiségi kedvezményeket alkalmaz. Kockázat szempontjából mind a két szerződésnek megvannak az egyedi rizikói, ezek mérlegelése és a vállalati vezetés kockázatvállalási hajlandóságától, illetve nagyságától függ, hogy melyik típust érdemes választani. Leegyszerüsítve a kérdést, mennyiségi kedvezményt abban a partnerkapcsolatban érdemes alkalmazni, ahol a kiskereskedő - vagyis a vevő rendelkezik nagyobb kockázatvállalási hajlandósággal. Míg visszavásárlási szerződést akkor érdemes választani, ha a nagykereskedö - vagyis az eladó - képes nagyobb kockázatot vállalni, hiszen ebben az esetben fennáll az el nem adott termékek visszavásárlásának lehetősége, mely többletköltséget és a készletszint megemelkedését eredményezi. Árérzékeny vállalatok esetén egyértelműen a mennyiségi kedvezmény javasolt. Amennyiben viszont a két fél hajlandó elviselni és kezelni a plusz ár-tényező által adott hátrányokat a magasabb profitértékek elérése érdekében, a visszavásárlási szerződés optimális megoldást nyújt.

Összegezve elmondható, hogy a számpélda alapján nem jelenthető ki egyértelmüen, melyik szerződés alkalmazása eredményezi biztosan a tagok közötti koordináció javulását. A számszerü példa elegendő volt arra, hogy megismerjük a szerződések müködési mechanizmusát, az árakban rejlő veszélyeket, az elérhető profitok értékét, és hogy mekkora értékesíthető mennyiséget képesek a tagok a szerződések segítségével elérni. Röviden, definiálhatóvá váltak az egyes szerződések mellett, illetve ellen szóló érvek, melyek befolyásolhatják a vállalatok döntéseit. A nagyobb profit elérése nagyobb kockázattal is jár. Amennyiben ezt a kockázatot képesek és hajlandóak viselni a vállalatok, a visszavásárlási szerződés potenciálisan jó megoldás lehet a számukra. Ekkor a 
visszavásárlási ár költségnövelö tényezöként jelenik meg, illetve a készletek növekedésének a veszélye is jelen van - föként az eladói szerepben levő lánctagnál. Azok a vállalatok, amelyek inkább a hagyományos megoldásokban bíznak, érdemes a mennyiségi kedvezmény szerződését választani.

Nem elhanyagolható azonban az a tény, hogy ezek a szerződések rugalmasan változtathatók, illetve kombinálhatók. Ezért érdemes megemlíteni, hogy a két szerződés ötvözése sincs kizárva. Ezzel a megoldással feltehetőleg egy még magasabb koordinációs erőt képviselő, a mennyiségi kedvezmény esetén elérhető profitoktól nagyobb profitértékekkel rendelkező és hatékonyabb működést eredményező hibrid szerződés jöhet létre. Jövőbeli kutatási irányzat lehet megvizsgálni azt, hogy milyen eredményeket produkálhat egy hibrid szerződés, mely a mennyiségi és a visszavásárlási szerződésből jön létre. Járható útnak tűnik az, hogyha a visszavásárlási ár is hasonlóan viselkedne, mint a mennyiségi kedvezményi árak. Tehát minél nagyobb a vásárolt mennyiség, annál alacsonyabb lenne a visszavásárlási ár is. Hasonló számpéldával, szcenárióval, illetve szekunder kutatás segítségével, akár valós vállalati helyzetben is érdemes lehet megvizsgálni, tesztelni ezt a lehetőséget a jövőben.

\section{3. Összegzés}

Az ellátásilánc-menedzsment egyik legnagyobb problémája a lánctagok közötti koordináció megfelelő szintü biztosítása. Rengeteg lehetőség áll a rendelkezésre, ezek közül a szakirodalom szerint az egyik legígéretesebb a szerződések alkalmazása. Jelen cikk egy olyan specifikációkkal rendelkező ellátási lánc szakaszt vizsgált meg, ahol elsődleges cél a készletszintek alacsonyan tartása. Erre a célra a mennyiségi kedvezményre és a visszavásárlási szerződésre esett a választás. Mindkét szerződés esetében az értékesíthető mennyiség a kritikus pont, ugyanis így nincs esély arra, hogy feleslegesen nagy mennyiségü készletek halmozódjanak fel. A mennyiségi kedvezmény annál nagyobb kedvezmény elérését teszi lehetővé, minél nagyobb tételnagyságban vásárol a partner. Ezzel az eladó biztosítja magának a készletek biztos kifutását, azonban a vevőnél pont ellenkező hatás érhető el, amennyiben nem a keresleti elörejelzéseknek, információknak megfelelően alkalmazzák a mennyiségi kedvezményeket. A visszavásárlási szerződés ezzel szemben a vevő készleteinek felhalmozódását akadályozza meg, vagyis kötelezi az eladót, hogy a vevő által el nem adott termékeket, árukat egy meghatározott visszavásárlási áron visszavegye. Igy a vevőnek nem lesznek felesleges készletei, azonban az eladónak igen. Vagyis a helyzet fordított, mint a mennyiségi kedvezmény esetében.

A visszavásárlási szerződés ezáltal egy olyan ellátási láncon alkalmazható hatékonyan, ahol nagyrészt egyenletes a piaci kereslet, nincsenek nagy ingadozások és nem, vagy csak nagyon alacsony szinten és viszonylag ritkán változnak a vevői igények. Ebben az esetben minimalizálni lehet a kockázatát annak, hogy a második tag, mint vevő ne legyen képes értékesíteni termékeit, így az eladónak nem lesz szükséges visszavásárolni. Mégis ez a vevő részére biztonságot jelenthet, növelheti a bizalmi faktort a partnerviszonyukban, összességében javíthatja az együttmüködés minőségét és mértékét.

Rengeteg szerződéstípus létezik a gyakorlatban és a szakirodalomban egyaránt. Nagyon sokat közülük már különféle vizsgálat alá vetettek a kutatók, mely vizsgálatok föként a szerződések koordinációs erősségükre koncentráltak, vagyis azt elemezték, hogy a mennyire támogatják a partnerek együttmüködését. A megfelelő szerződéstípus kiválasztása stratégiai jelentőségü, ugyanis ellenkező hatást is képes kiváltani egy, nem a vállalati attitüdöknek és a kapcsolat jellegének megfelelő szerződés kiválasztása.

A szerződéstípusok kiválasztásának kérdését viszont meg lehet fordítani. Vagyis, nem is igazán az a kérdés, hogy melyik típust fogják a vállalatok választani, hanem az, hogy az adott helyzethez mérten, a vállalatok különböző szempontjai és tulajdonságai alapján milyen szerződés illene a hozzájuk a legjobban. Vagyis elsősorban nem azt kell megvizsgálni, hogy melyik szerződés rendelkezik jobb feltételekkel, hiszen az eltérő igények miatt elképzelhető, hogy egyes szerződések másképpen viselkednek egy teljesen más vállalati és partnerkapcsolati környezetben. Így egy ilyen szituációban elsődlegesen azt kell megvizsgálni, hogy a vállalatok számára mi a fontos. Ilyen kritériumok lehetnek az árak, azok rugalmas változtatására való igény, a rendelési tételnagyságra vonatkozó limitek beállítási lehetőségei, azok rugalmas kezelése, a készletek elkerülése vagy épp 
felhalmozása érdekében tett lépések, a magasabb profit elérésére vonatkozó információ megosztási hajlandóságok, egyéb szállítási feltételek és itt a lista még korántsem ért véget. Ehhez érdemes egy nagyobb mintával rendelkező empirikus kutatás elvégzése. Természetesen célszerü tisztában lenni a különféle szerződésekkel és azok tulajdonságaival, hogy az igényeknek megfelelő típust lehessen ajánlani, ezért tekinthető relevánsnak a cikkben található számszerü példa a mennyiségi kedvezmény és a visszavásárlási szerződés vizsgálatával. Van azonban lehetőség a konstrukciók megváltoztatására, bizonyos típusokat kombinálni egymással, hogy egy még elönyösebb keretfeltétel jöjjön létre a vállalati együttműködéshez. Ez jövőbeli kutatási irányzatokat vetít elöre.

\section{Köszönetnyilvánítás}

A cikkben/előadásban/tanulmányban ismertetett kutató munka az EFOP-3.6.1-16-2016-00011 jelü „Fiatalodó és Megújuló Egyetem - Innovatív Tudásváros - a Miskolci Egyetem intelligens szakosodást szolgáló intézményi fejlesztése" projekt részeként - a Széchenyi 2020 keretében - az Európai Unió támogatásával, az Európai Szociális Alap társfinanszírozásával valósul meg.

\section{Irodalomjegyzék}

[1] Chikán A.: Vállalatok és funkciók integrációja, A „Versenyben a világgal” - A magyar gazdaság versenyképességének mikrogazdasági tényezői c. kutatási program Mühelytanulmány sorozata, Z8 kötet, 1997

[2] Coltman, T., Bru, K., Perm-Ajchariyawong, N., Devinney, T. M., Benito, G. R.: Supply Chain Contract Evolution, European Management Journal, 2009, Vol. 27., Issue 6., pp. 388-401., DOI: 10.1016/i.emj.2008.11.005

[3] Faludi, T., Molnár, V.: Az ellátásilánc-koordinációhoz kapcsolódó stratégiai döntéstámogatási területek, Műszaki Tudomány az Észak-Kelet Magyarországi Régióban (szerk.: Bodzás Sándor), 2017, pp. 98-104

[4] Gomez-Padilla, A., Mishina, T.: Supply contract with options, International Journal of Production Economics, 2009, Vol. 122., No. 1., pp. 312-318, DOI: 10.1016/j.ijpe.2009.06.006

[5] Kujáni, K.: A rövid ellátási láncok tervezési feltételei a hazai kistérségekben, Gradus, 2017 Vol 4., No 2., pp. 222231

[6] Mentzer, J. T., DeWitt, W., Keebler, J. S., Min, S., Nix, N., Smith, C. D., Zacharia, Z. G.: Defining Supply Chain Management, Journal of Business Logistics, 2001, Vol. 22., No. 2., pp. 1-25, DOI: 10.1002/1.21581592.2001.tb00001.x

[7] Pfeiffer, T.: A comparison of simple two-part supply chain contracts, International Journal of Production Eonomics, 2016, Vol. 180, pp. 114-124., DOI: 10.1016/j.ijpe.2016.06.023

[8] Polo, M., Scarpa, C. (2013): Liberalizing the gas industry: Take-or-pay contracts, retail competition and wholesale trade, 2013, International Journal of Industrial Organization, Vol. 31, pp. 64-82, DOI: 10.1016/j.ijindorg.2012.10.003

[9] Shin, H., Benton, W. C.: A qunatity discount approach to supply chain coordination, European Journal of Operational Research, 2007, Vol. 180., Issue 2., pp. 601-616, DOI: 10.1016/j.ejor.2006.04.033

[10] Singh, R. K., Benyoucef, L.: A consensus based group based decision making methodology for strategic selection problems of supply chain coordination, Engineering Applications of Artificial Intelligence, 2013, Vol. 26., pp. 122134, DOI: 10.1016/j.engappai.2012.03.013

[11] Sluis, S., De Giovanni, P.: The selection of contracts in supply chains: An empirical analysis, Journal of Operations Management, 2016, Vol. 19., No. 8., pp. 3-8, DOI: 10.1016/j.jom.2015.10.002

[12] Szegedi, Z.: Ellátásilánc-menedzsment, Kossuth Kiadó. Budapest. 2017

[13] Tamás, P., Illés, B.: Novel trends in improvement of warehouse management systems for manufacturing companies, Academic Journal of Manufacturing Engineering, 2017, Vol. 15., No. 3., pp. 23-28.

[14] Tsay, A.: The Quantity Felxibility Contract and Supplier-Costumer Incentives, 1999, Management Science, Vol. 45., No. 10., pp. 1339-1358, DOI: $10.1287 /$ mnsc.45.10.1339

[15] Wang, X., Wang, X., Su, Y.: Wholesale-price contract of supply chain with information gathering, Applied Mathematical Modelling, 2013, Vol. 37., Issue 6., pp. 3848-3860, DOI: 10.1016/i.apm.2012.07.007

[16] Xiong, H., Chen, B., Xie, J.: A composite contract based on buy back and quantity flexibility contracts, European Journal of Operation Research, 2011, Vol. 210, pp. 559-567, DOI: 10.1016/i.ejor.2010.10.010

[17] Zhang, Q., Dong, M., Luo J., Segerstedt, A.: Supply chain coordination with trade credit and quantity discount incorporating default risk, International Journal of Production Economics, 2014, Vol. 153., pp. 352-360, DOI: 10.1016/j.ijpe.2014.03.019 